\title{
Potentiation of Amylase Release from Isolated Rat Parotid Cells-Studies on the Combination of Isoproterenol and a Low Dose of Carbachol
}

\author{
Haruo TAKEMURA \\ Department of Pharmacology, Sapporo Medical College, Sapporo 060, Japan \\ Accepted June 15, 1984
}

Amylase release from parotid gland due to carbachol (CCh), a cholinergic agonist, requires extracellular $\mathrm{Ca}^{2+}$ and is accompanied by an increased influx of $\mathrm{Ca}^{2+}$ into the cells $(1,2)$. On the other hand, both intracellular cyclic AMP and Ca participate in the regulation of amylase release by $\beta$ adrenergic agonists (3). $\mathrm{Ca}$ is also believed to regulate amylase releases induced by cyclic AMP in the salivary glands $(2,4)$ and stimulated by acetylcholine in the pancreas (5). Recently, it is assumed that a small increase in cytoplasmic $\mathrm{Ca}^{2+}$ would increase amylase release from the pancreas, whereas a higher concentration of $\mathrm{Ca}^{2+}$ would inhibit this enzyme release (5). My previous investigation showed that high doses of $\mathrm{CCh}$ inhibited the isoproterenol (ISP)-induced amylase release from parotid acinar cells (6). In the present work, the effect of a low dose of CCh on ISP-induced amylase release was studied using isolated rat parotid cells.

Isolated acinar cells were prepared from male Wistar rats $(250-300 \mathrm{~g})$ as described previously $(6,7)$. The cell suspension was preincubated for $15 \mathrm{~min}$ at $37^{\circ} \mathrm{C}$ under $100 \%$ $\mathrm{O}_{2}$ in $1 \%$ bovine serum albumin-containing medium which has the following composition $(\mathrm{mM}): \mathrm{NaCl}, 103 ; \mathrm{KCl}, 4.7 ; \mathrm{CaCl}_{2}, 2.56$; $\mathrm{MgCl}_{2}$, 1.13; $\mathrm{Na} \beta$-hydroxybutyrate, 5.0; $\mathrm{Na}$ pyruvate, 4.9; Na glutamate, 4.9; Na fumarate, 2.7: Tris (hydroxymethylethyl) aminomethane, $20.0(\mathrm{pH} \mathrm{7.4).} \mathrm{In} \mathrm{the} \mathrm{combination}$ experiments, $\mathrm{CCh}$ and atropine were added $5 \mathrm{~min}$ and $7 \mathrm{~min}$, respectively, before the addition of ISP. Amylase released from parotid cells into the medium during $30 \mathrm{~min}$ incubation was assayed by the method of Searcy et al. (8), and its release was expressed as the percent of amylase content (initial cell content) of the cells before the start of incubation. The amylase content of parotid cells before secretory stimulation was $727.9 \pm 3.9$ (S.E.M.) units/mg of cell protein $(n=11)$. Units of this enzyme activity were expressed as $\mu \mathrm{mol}$ of glucose formed per min at $37^{\circ} \mathrm{C}$. The cyclic AMP in the cell suspension during 2 min incubation was extracted by the method of Honma et al. (9) and assayed by a commercial assay kit (Yamasa Shoyu Co.). At 5, 10, 20 and $30 \mathrm{~min}$ after the addition of $\left[{ }^{3} \mathrm{H}\right]$ inulin $(5 \mu \mathrm{Ci} / \mathrm{ml})$ and ${ }^{45} \mathrm{CaCl}_{2}(1 \mu \mathrm{Ci})$ $\mathrm{ml})$, radioactivities of the cell pellets for ${ }^{3} \mathrm{H}$ and ${ }^{45} \mathrm{Ca}$ were counted simultaneously by a dualisotope liquid scintillation spectrometer (LS-9000, Beckman). The cellular uptake of ${ }^{45} \mathrm{Ca}^{2+}$ was estimated as the Ca space subtracted by the inulin space (6). The Ca space and inulin space of the cell pellets after 30 min incubation without drugs were $5.00 \pm 0.18$ and $3.67 \pm 0.23 \mu \mathrm{l} / \mathrm{mg}$ of cell protein $(n=6)$. respectively. The cell protein was determined by the method of Lowry et al. (10). The significance between values was examined by Student's $t$-test. The following drugs were used: (-)-Isoproterenol (+)-bitartrate (Sigma), carbachol (Sigma), atropine sulfate (Merck), ethyleneglycol bis- $\beta$-aminoethylether)-N,N'-tetraacetic acid (EGTA, Kantokagaku Co.), [ $\left.{ }^{3} \mathrm{H}\right]$ inulin $(199 \mu \mathrm{Ci} / \mathrm{mg}$. Amersham) and ${ }^{45} \mathrm{CaCl}_{2} \quad(19.8 \mathrm{mCi} / \mathrm{mg}$. Amersham).

The effects of a low dose $(0.1 \mu \mathrm{M})$ of $\mathrm{CCh}$ on amylase release and cyclic AMP levels are shown in Table 1. CCh slightly increased the amylase release and potentiated the ISP $(1 \mu \mathrm{M})$-induced amylase release. These effects of $\mathrm{CCh}$ were blocked by atropine $(10 \mu \mathrm{M})$ and abolished in Ca-free (1 mM EGTA) medium. The cell suspension 
Table 1. Effects of carbachol on amylase release and cyclic AMP level in isolated parotid cells

Amylase release (\% of initial cell content)

\begin{tabular}{|c|c|c|c|c|c|c|}
\hline \multirow[t]{2}{*}{ Additions } & \multicolumn{4}{|c|}{ Norma! medium } & \multirow{2}{*}{$\begin{array}{l}\text { Ca-free ( } 1 \mathrm{mM} \\
\text { EGTA) medium }\end{array}$} & \multirow[t]{2}{*}{$\begin{array}{l}\text { Cyclic AMP level } \\
\text { (pmol/mg protein) }\end{array}$} \\
\hline & Control & & Atropine (10 & $\mu \mathrm{M})$ & & \\
\hline None & $4.8 \pm 0.4$ & (7) & $4.0 \pm 0.4$ & (5) & $3.5 \pm 0.4$ & $3.29 \pm 0.22$ \\
\hline $\begin{array}{l}\text { Carbachol } \\
(0.1 \mu \mathrm{M})\end{array}$ & $6.5 \pm 0.5$ & (7) & $4.7 \pm 0.5^{*}$ & (5) & $3.9 \pm 0.5^{* *}$ & $2.88 \pm 0.32$ \\
\hline $\begin{array}{l}\text { Isoproterenol } \\
\qquad(1 \mu \mathrm{M})\end{array}$ & $26.2 \pm 1.2$ & (7) & $23.1 \pm 1.1$ & (5) & $22.1 \pm 2.8$ & $77.28 \pm 4.44$ \\
\hline $\begin{array}{r}+ \text { carbachol } \\
(0.1 \mu \mathrm{M})\end{array}$ & $35.5 \pm 2.78$ & $(7)$ & $21.9 \pm 1.8^{* *}$ & (5) & $22.0 \pm 2.7^{* *}(6)$ & $76.72 \pm 4.57$ \\
\hline
\end{tabular}

Parotid cells were incubated for $30 \mathrm{~min}$ and $2 \mathrm{~min}$ for amylase release and cyclic AMP level, respectively. In the combination experiments, carbachol and atropine were added $5 \mathrm{~min}$ and 7 min, respectively, before the addition of isoproterenol. Values are given as the mean \pm S.E., and the number of experiments is shown in parentheses. $\mathbb{I P}_{\mathrm{P}}<0.05$ vs. none; $\$ \$ \mathrm{P}<0.01$ vs. isoproterenol; ${ }^{*} \mathrm{P}<0.05,{ }^{*} \mathrm{P}<0.01$ vs. control.

was preincubated with $\mathrm{CCh}$ before the addition of ISP in this study; on the other hand, potentiation of amylase release was also observed when it was preincubated with ISP before the addition of CCh (data not shown). In contrast to the effects of $\mathrm{CCh}$ on amylase release, neither non-ISP-stimulated nor ISP-stimulated cyclic AMP levels were affected by CCh. The potentiating effect of cholinergic agonists on ISP-stimulated amylase release has been observed in rat parotid gland slices $(11,12)$ and in the parotid gland of rabbits (13). Since the effects of CCh on ISP-induced ${ }^{45} \mathrm{Ca}^{2+}$ uptake has not yet been observed, this effect was examined (Fig. 1). CCh (0.1 /M) alone slightly increased ${ }^{45} \mathrm{Ca}^{2+}$ uptake, which may induce a small increase in amylase release (Table 1). On the other hand, ISP (1 ":M) significantly increased ${ }^{45} \mathrm{Ca}^{2+}$ uptake at 10 and $30 \mathrm{~min}$, and this uptake was increased almost additively by CCh. The amounts of amylase release induced by ISP in the normal medium and in the $\mathrm{Ca}$-free medium did not significantly differ (Table 1). Therefore, ISPstimulated $\mathrm{Ca}^{2+}$ influx may not be involved in amylase releases induced by ISP alone and the combination of $\mathrm{CCh}$ and ISP. This assumption is supported by the report that the increased $\mathrm{Ca}^{2+}$ uptake due to ISP may result from pinocytosis, and this uptake due to $\mathrm{CCh}$ is ascribed to the stimulated transmembrane $\mathrm{Ca}^{2+}$ influx (14).

A high dose $(10 \mu \mathrm{M})$ of $\mathrm{CCh}$ had an

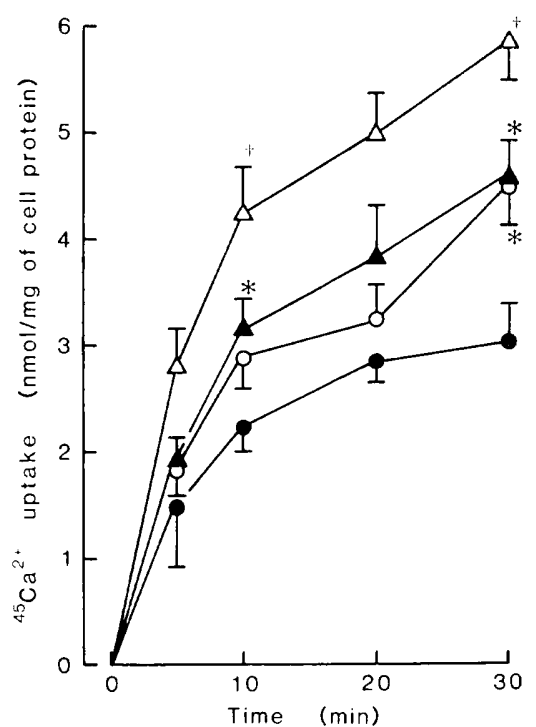

Fig. 1. Time course of ${ }^{45} \mathrm{Ca}^{2+}$ uptake into isolated parotid cells. In the combination experiment. carbachol was added $5 \mathrm{~min}$ before the addition of isoproterenol. Control, $C$ : carbachol $(0.1 \mu \mathrm{M})$. $\mathbf{A}$ : isoproterenol (1 $\mu \mathrm{M}), \Delta$ : carbachol $(0.1 \mu \mathrm{M})+$ isoproterenol $(1 \mu \mathrm{M})$. Each point is the mean $\pm \mathrm{S}$.E. of 6 experiments. ${ }^{*} \mathrm{P}<0.05$ vs. control, $\uparrow \mathrm{P}<0.05 \mathrm{vs}$. isoproterenol.

inhibitory effect on the ISP (1 $/ \mathrm{M})$-induced amylase release (6), in contrast to the stimulatory effect of a low dose $(0.1 / \mathrm{M})$ of CCh (Table 1). On the other hand, the increment of ISP-stimulated ${ }^{45} \mathrm{Ca}^{2+}$ uptake 
due to a low dose of CCh (Fig. 1) was about $1 / 3.5$ of that at high dose of $\mathrm{CCh}$ (6). Moreover, these doses of $\mathrm{CCh}$ had no effect on cyclic AMP accumulation stimulated by 1 / M ISP (Table 1, (6)), but had an inhibitory effect on that at higher concentrations $(>1 \mu \mathrm{M})$ of ISP (15). These facts suggest that the influx of $\mathrm{Ca}^{2+}$ induced by $\mathrm{CCh}$ has both stimulatory and inhibitory effects on condition that the increased level of cyclic AMP in parotid cells is not altered. Since ISP $(1 / \mathrm{M})$ stimulated ${ }^{45} \mathrm{Ca}^{2+}$ efflux from rat parotid cells, showing $\mathrm{Ca}^{2+}$ release from intracellular storage sites $(2,16)$, the combination of $\mathrm{Ca}^{2+}$ entry due to $\mathrm{CCh}$ and $\mathrm{Ca}^{2+}$ release due to ISP may result in a moderate elevation of cytoplasmic $\mathrm{Ca}^{2+}$ level, which could potentiate amylase release from parotid cells. However, the range of cytoplasmic $\mathrm{Ca}^{2+}$ concentration which brings about the potentiation of amylase release seems to be narrow, because ISP-induced amylase release was not affected by a lower dose $(0.01 \mu \mathrm{M})$ of $\mathrm{CCh}$ (data not shown) and was inhibited by higher doses $(\geqq 1 \mu \mathrm{M})$ of $\mathrm{CCh}$ (6). In fact, $\mathrm{Ca}^{2+}$, as an intracellular mediator during amylase secretion, is most effective in the comparatively narrow range of $\mathrm{Ca}^{2+}$ concentrations between 0.4 and $1 \mu \mathrm{M}$ (17).

The present results suggest that a low dose $(0.1 \mu \mathrm{M})$ of CCh slightly increases $\mathrm{Ca}^{2+}$ influx from the extracellular medium into parotid cells, and this increase may result in a moderate increase in cytosolic free $\mathrm{Ca}^{2+}$ which potentiates the ISP-induced amylase release.

\section{References}

1 Putney, J.W., Jr.: Stimulation of ${ }^{45} \mathrm{Ca}$ influx in rat parotid gland by carbachol. J. Pharmacol. Exp. Ther. 199, 526-537 (1976)

2 Butcher, F.R. and Putney, J.W., Jr.: Regulation of parotid gland function by cyclic nucleotides and calcium. Adv. Cyclic Nucleotide Res. 13, 215-249 (1980)

3 Butcher, F.R.: Calcium and cyclic nucleotides in the regulation of secretion from the rat parotid by autonomic agonists. Adv. Cyclic Nucleotide Res. 9, 707-721 (1978)

4 Putney, J.W., Jr., Weiss, S.L., Leslie, B.A. and Marrier, S.H.: Is calcium the final mediator of exocytosis in the rat parotid gland? J. Pharmacol. Exp. Ther. 203, 144-155 (1977)

5 Williams, J.A.: Regulation of pancreatic acinar cell function by intracellular calcium. Am. J. Physiol. 238, G269-G279 (1980)

6 Takemura, H.: Inhibitory effect of carbachol on isoproterenol-induced amylase release from isolated rat parotid cells. Japan. J. Pharmacol. 35, 9-17 (1984)

7 Takemura, $H$. and Ohshika, $H$.: Reactivity of isolated rat parotid cells to $\alpha$-and $\beta$-adrenergic agents. Sapporo Med. J. 51, 429-437 (1982) (Abs. in English)

8 Searcy, R.L., Hayashi, S. and Berk, J.D.: A new micro saccharogeric method for serum amylase determination. Am. J. Clin. Pathol. 46, 582-586 (1966)

9 Honma, M., Satoh, T., Takezawa, J. and Ui, M.: An ultrasensitive method for the simultaneous determination of cyclic AMP and cyclic GMP in small-volume samples from blood and tissue. Biochem. Med. 28, 257-273 (1977)

10 Lowry, O.H., Rosebrough, N.J., Farr, A.L. and Randall, R.J.: Protein measurements with the Folin reagent. J. Biol. Chem. 193, 265-275 (1951)

11 Templeton, D.: Augmented amylase release from rat parotid gland slices, in vitro. Pfluegers Arch. 384, 287-289 (1980)

12 Spearman, T.N. and Butcher, F.R.: Rat parotid gland protein kinase activation. Relationship to enzyme secretion. Mol. Pharmacol. 21, 121-127 (1981)

13 Asking, B. and Gjöstrup, P.: Effects of carbachol on isoprenaline evoked amylase release from the rabbit parotid gland in vitro. Acta Physiol. Scand. 109, 415-420 (1980)

14 Putney, J.W., Jr., Van De Walle, C.M. and Leslie, B.A.: Receptor control of calcium influx in parotid acinar cells. Mol. Pharmacol. 14, 1046-1053 (1978)

15 Oron, Y., Kellogg, J. and Larner, J.: Alpha adrenergic and cholinergic-muscarinic regulation of adenosine cyclic $3^{\prime}, 5^{\circ}$-monophosphate levels in the rat parotid. Mol. Pharmacol. 14, 10181030 (1978)

16 Butcher, F.R.: Regulation of calcium efflux from isolated rat parotid cells. Biochim. Biophys. Acta 630, 254-260 (1980)

17 O'Doherty, J. and Stark, R.J.: Stimulation of pancreatic acinar secretion: increase in cytosolic free calcium and sodium. Am. J. Physiol. 242, G513-G521 (1982) 